\title{
Mapping of Local Government Internal Control System Problems: A Content Analysis
}

\author{
Sri Rahayu ${ }^{1, *}$ Yudi $^{2, *}$ Rahayu $^{3}$ \\ ${ }^{1,2,3}$ Acounting Department, Faculty of Economic and Bussiness, Universitas Jambi \\ *Corresponding author, Email:sri_rahayu@unja.ac.id; srijambi@gmail.com
}

\begin{abstract}
The purpose of this study is to map the problems with the implementation of an internal control system in the local government. A qualitative approach through a method of content analysis is used in this research. The analysis used is the Leximancer instrument. The data used derived from audit reports of Badan Pemeriksa Keuangan (BPK) 2014-2018 years. The subject of study is the districts and city done the segregation in Jambi Province. The result showed the implementation of the information systems and communication and the optimal monitoring have implemented. Environmental element control has been applied but still needs to optimize particularly related to the competence of employees, discipline, and ethics enforcement employees. Element risk assessment and activity control is still must be attention, although has also started to adopted by regional governments. Internal control over assets especially fixed assets needs to be special attention to local governments. Conclusions overall all the internal control system has been implemented while still there were several weaknesses, fore that still need to be optimized.
\end{abstract}

Keywords: Control Environment, Risk Assessment, Control Activities, Information and Communication Systems, Monitoring.

\section{INTRODUCTION}

Government organizations including local governments are frequently criticized. Some of the criticisms include the low ability for creativity and innovation, lack of discipline, low quality of work and less productivity [1], large and inefficient [2], still considered wasteful [3], low capacity for human resources [4] and the level of corruption that still needs to be resolved [5]. Improvements are expected to emerge from the reform process. Management of government organizations has become one of the targets for reform [6]. The transfer of authority from the central government to the regions increases through regional autonomy so that it is given more flexibility to run the government [7] than before the reform era.

Reform has also been carried out in government financial management so that it is always an interesting topic to discuss because it involves people's lives. Local governments in carrying out their activities follow the new public management (NPM) pattern. Experts see that NPM will be able to solve various problems in government organizations so that they carry out their operations like private organizations [2]. Christensen dan Lægreid Christensen and Lægreid [8] even states that NPM is also one of the concepts that focus on improving the response of public institutions to society, efficiency and accountability, and government performance.

Local governments are obliged to be accountable for all funds from any source they manage for the delivery of services to the community. The results of financial accountability in the form of financial reports are submitted to stakeholders. Financial reports can be used to assess the financial condition [9] and financial health [10] of local governments.

The Financial audit is an activity to check the quality of financial reports, accountability, implementation of internal controls, conformity with applicable standards and regulations. Audit of local government financial reports is conducted annually by (Indonesian Supreme Audit Institution) or BPK as the government's external auditor. The audit results are stated in the examination results report and opinion statement. The five types of opinions given from the audit results are unqualified opinion, modified unqualified opinion, qualified opinion, disclaimer, and adverse. The development of audit opinion for the financial reports of districts and cities in Jambi Province can be seen in table 1 . 
Table 1. District/City Financial Report Audit Opinion in Jambi Province for 2011 - 2019

\begin{tabular}{|c|c|c|c|c|c|c|c|c|c|c|}
\hline No & City/District & 2011 & 2012 & 2013 & 2014 & 2015 & 2016 & 2017 & 2018 & 2019 \\
\hline 1 & Jambi & $\mathrm{Q}$ & $\mathrm{Q}$ & $\mathrm{Q}$ & $\mathrm{Q}$ & $\mathrm{Q}$ & UQ & UQ & UQ & UQ \\
\hline 2 & Muaro Jambi & Q & Q & UQ & UQ & Q & $\mathrm{Q}$ & UQ & UQ & UQ \\
\hline 3 & Merangin & Q & Q & Q & Q & Q & UQ & UQ & UQ & UQ \\
\hline 4 & $\begin{array}{l}\text { Tanjung Jabung } \\
\text { Barat }\end{array}$ & Q & Q & Q & Q & Q & Q & D & UQ & UQ \\
\hline 5 & $\begin{array}{l}\text { Tanjung } \\
\text { Jabung Timur }\end{array}$ & Q & Q & MUQ & MUQ & Q & UQ & Q & UQ & UQ \\
\hline 6 & Batanghari & Q & Q & MUQ & MUQ & Q & Q & UQ & UQ & UQ \\
\hline 7 & Bungo & Q & Q & Q & Q & Q & UQ & Q & UQ & UQ \\
\hline 8 & Kerinci & $\mathrm{Q}$ & $\mathrm{Q}$ & $\mathrm{Q}$ & $\mathrm{Q}$ & MUQ & $\mathrm{Q}$ & UQ & UQ & UQ \\
\hline 9 & Sarolangun & $\mathrm{Q}$ & $\mathrm{Q}$ & $\mathrm{Q}$ & $\mathrm{Q}$ & Q & UQ & UQ & UQ & UQ \\
\hline 10 & Tebo & Q & $\mathrm{Q}$ & Q & $\mathrm{Q}$ & $\mathrm{Q}$ & UQ & UQ & UQ & UQ \\
\hline 11 & Sungai Penuh & Q & Q & UQ & Q & MUQ & $\mathrm{D}$ & UQ & UQ & UQ \\
\hline
\end{tabular}

(UQ= unqualified, MUQ=modified UQ, Q=qualified, D=Disclaimer Source: BPK Jambi

Based on the table above, it can be seen that for the results of the audit of the 2018 and 2019 financial statements, all districts and cities in Jambi Province have received an unqualified opinion. This is quite an encouraging achievement in terms of the quality of local government financial reports. However, if traced to the BPK Audit Result Report, several findings are still found related to weaknesses in the government's internal control system.

Obtaining the WTP opinion also does not guarantee the completion of all regional financial management issues. BPK still finds that the use of state money is inefficient and ineffective [11]. One of the ways to improve financial management is to improve weaknesses in the government's internal control system. The Government's Internal Control System defines internal control as an integral process of actions and activities carried out continuously by the leadership and all employees to provide adequate confidence in the achievement of organizational goals through effective and efficient activities, reliability of financial reporting, consumption of state assets and compliance with laws and regulations [12].

Research on financial management both in private and in local governments has been widely studied in Indonesia by accounting researchers. However, research on the weaknesses of the Government Internal Control System using content analysis on BPK audit reports has not been widely carried out. Therefore, this study aims to map the weaknesses of the local government internal control system using content analysis.

\section{METHODS}

This study used a qualitative research design. Qualitative Research allows researchers to explore more deeply certain specific things [13] which cannot necessarily be extracted from a quantitative approach.
The data to be used in this research is secondary data in the form of a BPK examination report. The subjects of this study were the districts and cities of segregation in Jambi Province which consisted of five regions. The BPK audit report used is from 2014 to 2018. The object of this research is the weakness of government internal control which is divided into five elements in accordance with Government Regulation No. 60 of 2008, namely control environment, risk assessment, control activities, information and communication, and control monitoring.

Content Analysis is used as a technique for data analysis. Berelson [14], One of the early initiators of content analysis stated that this technique can be used to analyze and understand the text. The information obtained is described in an objective, systemic and quantitative manner. [15] defines content analysis as a research method for determining the presence of words or concepts in a text or a set of texts. $\mathrm{n}$ working on the Content Analysis method, a coding mechanism is needed to classify the data to be analyzed [16]. The data analysis stages consist of open coding, axial coding, and selective coding. The tool used to assist the content analysis process using Leximancer 4.51. Leximancer is often used for qualitative research besides NVivo. NVivo 12 Plus does have one of the advantages of processing qualitative data efficiently and effectively in large quantities, both from documents, interviews, observations, and FGDs [17]. However, NVivo still requires manual handling of data at various points, meanwhile, Leximancer provides a form of automated analysis based on the properties of text. The Leximancer results will show the dominant themes and concepts from the results of the content analysis as well as the relationship between themes [18]. Another advantage of Leximancer has a good level of data validity. Measurement of data reliability uses the prominence of each concept, with limits considered 
reliable $\geq 0,5$. The level of visible concept used $100 \%$, while for the Theme size 33\%. The likelihood level for related word-like is not limited by researchers, to obtain a more comprehensive picture.

\section{RESULT AND DISCUSSION}

\subsection{Findings and Recommendations Related to The Government's Internal Control System}

The focus of internal control, which is evaluated by the BPK in the financial report audit process, is related to the internal control system for financial reports. Although the objective of the BPK audit is the examination of local government financial reports, consideration of the internal control system is carried out to determine audit procedures to express an opinion on the financial statements. The development of the number of findings and recommendations related to the government's internal control system in the five regions of the segregation of Jambi Province can be seen in table 2 .
Table 2. Findings and recommendations in the five regions of the segregation of Jambi Province For 2014 $-2018$

\begin{tabular}{|c|c|c|}
\hline \multirow{2}{*}{ Year } & \multicolumn{2}{|c|}{ Number of } \\
\cline { 2 - 3 } & Findings & Recommendation \\
\hline 2014 & 36 & 42 \\
\hline 2015 & 37 & 41 \\
\hline 2016 & 33 & 36 \\
\hline 2017 & 31 & 35 \\
\hline 2018 & 22 & 23 \\
\hline
\end{tabular}

Based on table 2, it can be seen that there is a tendency for the number of findings related to weaknesses in the government's internal control system. This is also in line with the decreasing trend in the number of recommendations given by the BPK to improve the government's internal control system. However, based on data analysis it is known that some weak findings are repeated every year. This shows the potential for an optimal improvement in the government's internal control system.

The results of data processing using Leximancer for the main weaknesses of the internal control system for the 2014-2018 financial statements show five emerging themes, namely administration, budgeting, fixed assets, cash, and funds. The dominant concept that appears in fixed assets consists of land, buildings, equipment, irrigation, and roads. The relationship between themes can be seen in Figure 1.

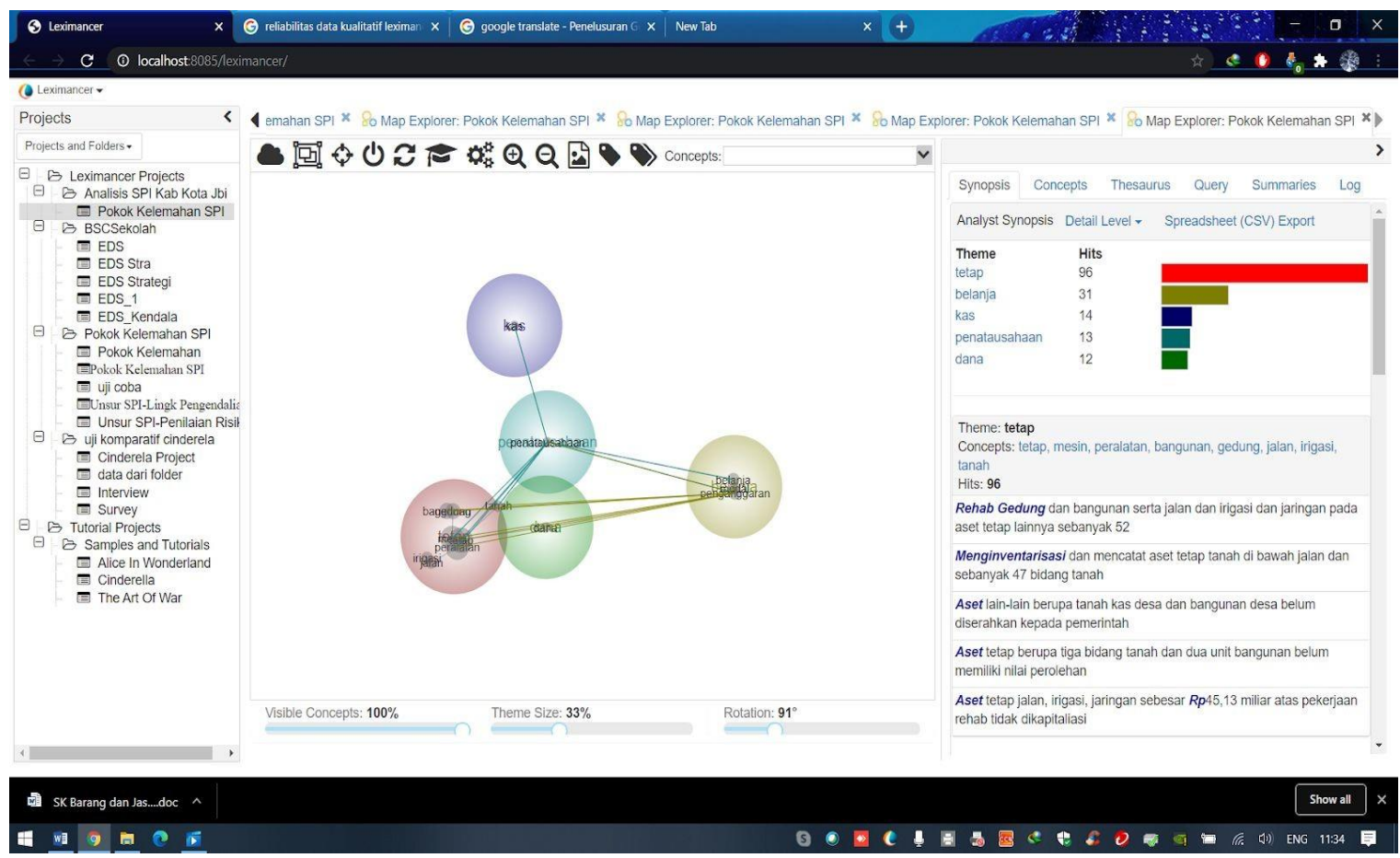

Picture 1. The theme of main weaknesses of internal control system Source: processed data

The theme of budgeting is related to the concept of capital spending with a relevance level of $89 \%$. The theme of capital expenditure budgeting is related to fixed assets such as land, machinery, and equipment as well as buildings. One of the forms is misclassification of spending, especially for renovation spending. Apart from that, the theme of budgeting also has strong relevance to funding. Funds, in this case, relate to budgeting problems in School Operational Assistance 
funds, Grant Aid Funds, and Village Funds and village fund allocations.

The governance theme has the strongest conceptual relationship with the fixed asset concept and cash concept. The forms of weakness in fixed assets that were found included the existence of assets, proof of ownership, the transfer of assets between the province or the parent district and the expansion areas, and the classification of expenditures.
3.2. BPK Recommendations to Improve the Weaknesses of the Government's Internal Control System

Based on the main weaknesses of the government's internal control system, the BPK provides recommendations that must be followed up by the regional government. One of the objectives of this recommendation is to improve so that it is hoped that the same weaknesses will not be found in the following year. The results of data processing for recommendations can be seen in Figure 2.

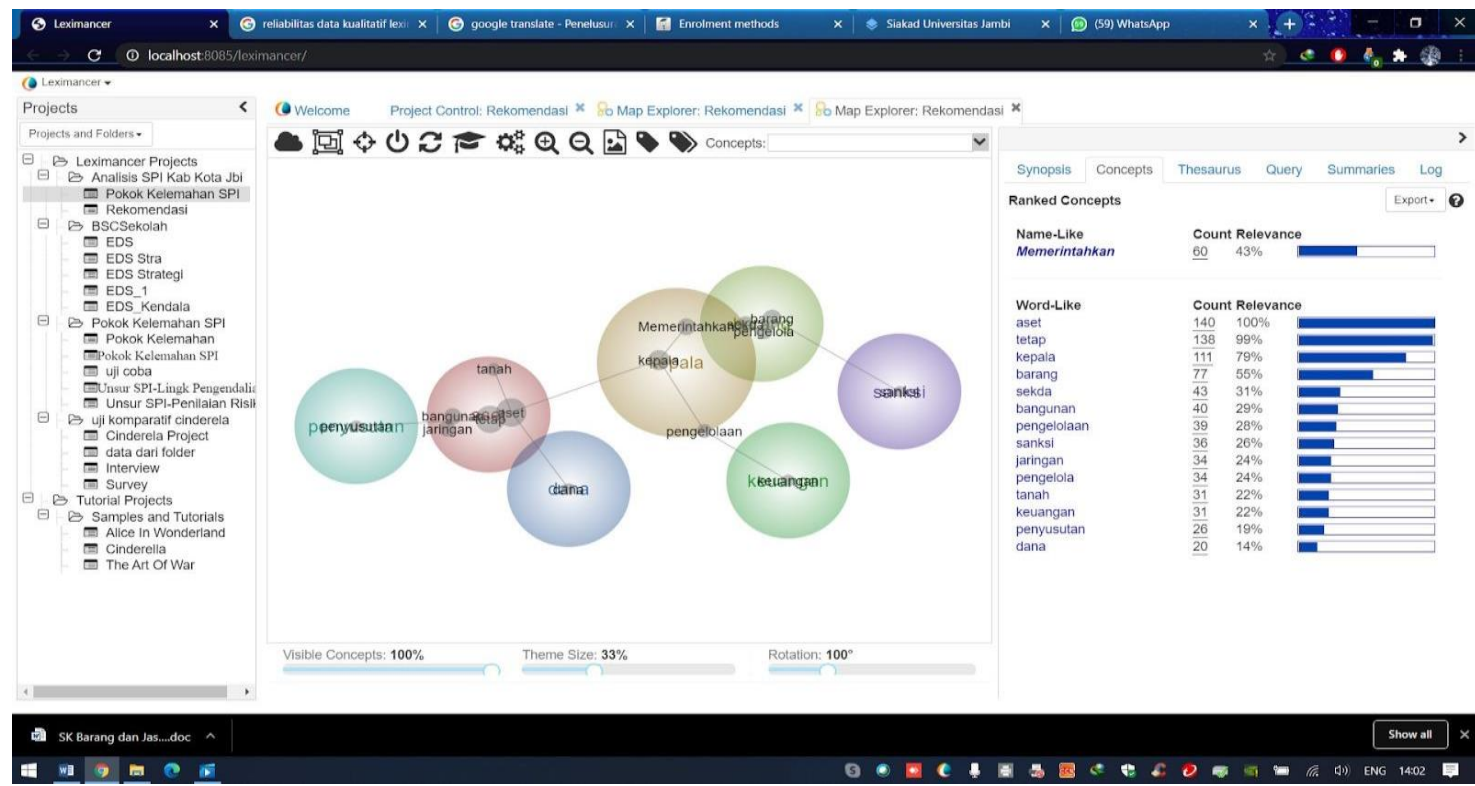

Picture 2. the theme of Recommendation on main weaknesses of internal control Source: processed data.

Based on Figure 2 above, it can be seen that the big theme that appears for recommendations is ordering improvements in management. The highest concept relates to assets, especially fixed assets. Most of the recommendations for fixed assets are related to improving the management of buildings and structures, roads, irrigation, and networks as well as land.

The BPK provides recommendations for improving asset management and administration, most of which are addressed to the head of the regional apparatus as the user of regional government assets to regulate asset management within its work unit. The Regional Secretary is the manager of regional assets and head of the regional government budget team. Besides, recommendations for asset management are also given to the goods manager. Regarding cash management, most recommendations are given to the Regional General Treasurer and regional financial and asset management agencies/offices (DPPKAD).

The results of the content analysis in the recommendations section are consistent with the main weaknesses of the government's internal control system in the previous sub-chapter. The discussion regarding the weaknesses for each element will be discussed next.

\subsection{Elements of Government Internal Control}

\subsubsection{Control Environment}

The control environment regulates that the leadership of government agencies and all employees must create and maintain an environment in the entire organization to cause positive behavior and support healthy internal management control. The control environment applied by most local governments has been quite good as evidenced by the fact that the whole has regulations related to organizational structures and work procedures that indicate a clear division of responsibilities and authorities.

Several things that still need to be optimized are related to policies and implementation of ethics and employee discipline. Local governments still use PNS disciplinary regulations from the central government. $n$ the last two years most regions have had mechanisms and procedures as well as requirements for assessing the competence of employees for structural positions. However, this has not been determined for employees who are assigned to certain functions such as accounting and financial reporting. Therefore, it is still found that the placement of employees is not in 
accordance with their educational background, knowledge, and skills.

\subsubsection{Risk Assessment}

Internal control must also be able to provide an assessment of the risks faced by organizational units, which come from outside the organization and from within the organization. From 2014 to 2016 there were still local governments that had not yet identified risks, especially at the work unit level. This results in the inability to do risk elimination as a form of prevention of potential risks.

In 2017 and 2018, almost all regions had identified risks. However, most of the risk assessment activities are still carried out up to the risk identification stage. The risks that have been found have not been further analyzed related to the causative factors, as well as solutions that must be done to eliminate these risks.

\subsubsection{Control Activities}

Control activities assist and ensure that directives of government agency leaders are implemented. Control activities must be effective and efficient in achieving organizational goals.

The results of the content analysis show that the local government has carried out quite good control activities, especially in relation to providing printed serial numbers on documents. Control activities that need to be optimized are, among others, related to securing and restricting access to asset storage space such as inventory and processing documents or data that have not been adequately designed. Some regions still use hardcopy documents and have not kept them in softcopy. Besides, local governments must also pay attention to controlling the management of funds and assets originating from school operational assistance.

\subsubsection{Information and Communication Systems}

Information and communications are recorded and reported to the head of government agencies and other designated parties. Information is presented in a specific form and means and on time so that the leadership of government agencies carries out control and responsibilities. Overall, the information and communication systems implemented by all regions are quite good. This is evidenced by the use of information technology in the process of preparing financial statements. The system used has also been well socialized, employees already know their duties and functions well. The communication established by the regional head with the heads of regional apparatus/government agencies is carried out through a coordination meeting of the evaluation meeting. Likewise, at the work unit level, the head of the regional apparatus routinely communicates regarding performance achievement through internal meetings.
Information and communication systems that still need to be optimized include the management of regional receivables. Some regions still use accounts receivable management systems that are not yet integrated with financial reporting. There are even regions that manually manage regional receivables (local retribution and local taxes).

\subsubsection{Monitoring}

Monitoring must be able to assess the quality of performance from time to time and ensure that recommendations on the results of audits and other reviews can be immediately followed up. Based on the results of the data analysis, information was obtained that all regions had been monitoring the implementation of activities regularly. Monitoring is carried out in three ways, namely inherent supervision carried out by direct supervisors of performance achievements in their work units, supervision is carried out by the government functional supervisory apparatus (APFP), namely the regional inspectorate through supervisory activities in accordance with the annual supervisory work program. Monitoring is also carried out through legislative supervision by DPRD.

Weaknesses are still found related to supervision, for example, the focus of supervision is more on the findings of the current year and compliance with laws and regulations. Besides, even though the follow-up has been monitored, it is still found that several recommendations from the $\mathrm{BPK}$ have not been followed up by the local government.

Based on the analysis of the application of the elements of the internal control system in the extended regional government in Jambi Province, it has been designed quite well, but still needs to be optimized. Some of the terms used in the report include there are still weaknesses, not fully effective yet, not completely adequate, and still found problems.

\section{CONCLUSIONS AND IMPLICATION}

The acquisition of unqualified opinions by almost all regions in Jambi province in 2018 and 2019 is a good achievement related to the quality of financial reports. However, there are still some weaknesses in implementing good internal control. This study uses a qualitative approach with content analysis. The data were obtained from the 2014 to 2018 BPK audit report for the city and district segregation in Jambi province. The analytical tool used is Leximancer 4.51.

In the future, local governments must focus on continuing to improve internal control for all elements. The control environment must be formulated and implemented by regional policies related to ethics enforcement and employee discipline in assigning employees according to competence, especially for certain positions. In-depth analysis of the results of risk identification, optimization of control activities, 
integrating information systems related to the management of regional receivables and fixed assets, and optimization of monitoring. The role of the Regional Secretary as the manager of regional assets and the head of the regional government budget team as well as the Head of Regional Apparatus as the user of regional assets and the regional general treasurer is very important for improving assets and cash management in local governments.

\section{ACKNOWLEDGMENT}

The Research Team would like to thank the Chancellor, Chair of the LPPM, and the Dean of the Faculty of Economics and Business, Jambi University for funding this research.

\section{REFERENCES}

[1] M. Mahmudi, Manajemen Kinerja Sektor Publik, Akademi Manajemen Perusahaan YKPN, Yogyakarta, 2005.

[2] K. Brown, J. Waterhouse, C. Flynn, Change Management Practices, International Journal of Public Sector Management, 162003 230-241.

[3] BPK, Ikhtisar Hasil Pemeriksaan Semester I 2018, in: B.P.K. RI (Ed.), BPK RI, Jakarta, 2018.

[4] G.M. Guess, Comparative Decentralization Lessons from Pakistan, Indonesia, and The Philippines, Public Administration Review, 65 2005 217-230.

[5] C. Polidano, The New Public Management in Developing Countries, Institute for Development Policy and Management, University of Manchester1999.

[6] Y. Anggarini, B.H. Puranta, Anggaran berbasis kinerja: Penyusunan APBD secara komprehensif, Unit Penerbit dan Percetakan (UPP) Sekolah Tinggi Ilmu Manajemen (STIM) YKPN2010.

[7] R. Zelmiyanti, Pendekatan Teori Keagenan pada Kinerja Keuangan Daerah dan Belanja Modal (Studi pada Provinsi di Indonesia), Jurnal Riset Akuntansi dan Komputerisasi Akuntansi, 72016 11-21.

[8] T. Christensen, P. Lægreid, Performance, and accountability - A Theoretical Discussion and An Empirical Assessment, Public Organization Review, 152015 207-225.

[9] I.T. Ritonga, Analysing the Quality of Accrual Accounting Implementation in Indonesia Local Governments, Jurnal Akuntansi, 222018 162-172.

[10] M. Iqbal, Desain Formulasi Penilaian Kinerja Kesehatan Fiskal Dan Pengelolaan Keuangan Daerah (Studi Kasus Provinsi Jawa Barat), Jurnal BPPK: Badan Pendidikan dan
Pelatihan Keuangan, 102017 13-13.

[11] BPK, Ikhtisar Hasil Pemeriksaan Semester I 2019, in: B.P.K. RI (Ed.), BPK RI, Jakarta, 2019.

[12] P.P. PP, Tentang Sistem Pengendalian Intern Pemerintah, 2008.

[13] J.W. Creswell, Research Design Pendekatan Kualitatif, Kuantitatif dan Mixed, Pustaka Pelajar, Yogyakarta, 2013.

[14] B. Berelson, Content Analysis in Communication Research, The Free Press, Glencoe III, 1952.

[15] I. Gunawan, Metode Penelitian Kualitatif Teori dan Praktik, Bumi Aksara, Jakarta, 2013.

[16] T. Sougi, S. Rahayu, A. Machpuddin, Analisis Temuan Pemeriksaan BPK-RI atas Aset Tetap pada Laporan Keuangan Pemerintah Kabupaten Merangin, Pemerintah Kabupaten Tanjung Jabung Barat, Pemerintah Kabupaten Tanjung Jabung Timur pada Tahun Anggaran 2014-2016, Jurnal Akuntansi Keuangan UNJA, 32018 34-40.

[17] A. Bandur, Penelitian Kualitatif: Studi Multi Disiplin Keilmuan dengan NVivo12 Plus, Mitra Wacana Media, Jakarta, 2019.

[18] P. Sotiriadou, J. Brouwers, T.-A.J.A.o.L.R. Le, Choosing a Qualitative Data Analysis Tool: A comparison of NVivo and Leximancer, Annals of Leisure Research, 172014 218-234. 